\title{
Sex Discrimination, the Civil Rights Act of 1964, Equal Pay, and Title IX as Applied to the Women's National Soccer Team
}

\author{
Richard J. Hunter, Jr. ${ }^{1}$, Héctor R. Lozada ${ }^{1} \&$ Gary H. Kritz ${ }^{1}$ \\ ${ }^{1}$ Seton Hall University, South Orange, New Jersey, USA \\ Correspondence: Héctor R. Lozada, Stillman School of Business, Seton Hall University, South Orange, New \\ Jersey 07079, USA. Tel: 1-973-761-9259. E-mail: hector.lozada-vega@shu.edu
}

Received: June 9, 2021

doi:10.5539/jpl.v14n4p55
Accepted: July 20, $2021 \quad$ Online Published: July 22, 2021

URL: https://doi.org/10.5539/jpl.v14n4p55

\begin{abstract}
This article presents the issues of sex discrimination, working conditions, and equal pay raised in the legal dispute between the United States Soccer Federation and the Women's National Soccer Team. The authors study the application of the Civil Rights Act of 1964 and the Equal Pay Act of 1963, and the implications of applying Title IX of the Education Amendments of 1972 to the U.S. Soccer Federation. The authors conclude by offering some observations and suggestions on the practical course of action that the US Women's Soccer Team may consider in attempting to solve its dispute with the Federation.
\end{abstract}

Keywords: U.S. Women's Soccer, Civil Rights Act of 1964, Equal Pay Act, Title IX, employment discrimination

\section{Introduction}

On March 8, 2021, Congresswomen Doris Matsui and Rosa DeLauro introduced the Give Our Athletes Level Salaries (GOALS) Act to ensure that the members of the U.S. Women's National Team are paid fair and equitable wages compared to the U.S. Men's team (Matsui, 2021). The GOALS Act threatens to cut federal funding for the 2026 World Cup if the U.S. Soccer Federation does not comply. As of June 9, 2021, more than a dozen Senate Democrats have introduced a bill that will accomplish this.

While the future of these bills is still uncertain at the time of this writing, this article explores the various issues raised in the legal dispute between the United States Soccer Federation and the Women's National Soccer Team. After laying out the basis for the dispute, we first consider the application of the Civil Rights Act of 1964 and the Equal Pay Act of 1963 as they relate to the dispute. We then discuss the potential implications of applying Title IX of the Education Amendments of 1972 to the U.S. Soccer Federation. Our paper ends with observations and suggestions on the options that the Women's National Team may have going forward.

\section{Title VII of the Civil Rights Act of 1964}

Issues relating to discrimination based on sex arising under various federal and state statutes have been frequently litigated in the American judicial system. The most recent decision in Bostock v. Clayton County, Georgia (2020) raised questions that were not traditional-but nonetheless important. On June 15, 2020, in 6-3 vote deciding Bostock, the United States Supreme Court concluded that Title VII of the Civil Rights Act of 1964 protects gay, lesbian, and transgender people from discrimination in employment on the basis of sex, one of the protected categories under the act (Carter, 2020; Sherman, 2020; Turner, 2020).

In Bostock and two companion cases, Altitude Express Incorporated v. Zarda (2020) and Harris v. EEOC (2020), the Supreme Court had been asked to decide two discreet questions:

- Does Title VII of the Civil Rights Act of 1964, which prohibits employment discrimination "because of ... sex," encompass discrimination based on an individual's sexual orientation?

- Does Title VII of the Civil Rights Act of 1964 prohibit discrimination against transgender employee based on (1) their status as transgender or (2) sex stereotyping?

Justice Neil Gorsuch, a Trump appointee to the Supreme Court, authored the majority opinion and answered affirmatively these two questions (Valenti, 2021). Justice Gorsuch wrote for the Court that "an employer who fires an individual for being homosexual or transgender fires that person for traits or actions it would not have questioned in members of a different sex" and that "sex plays a necessary and undisguisable role in the decision, 
exactly what Title VII forbids" (quoted in Legault, Pasternak, Lawless, \& Clark, 2020).

The decision in Bostock was only the most recent one dealing with discrimination based on sex decided under the Civil Rights Act of 1964. While expanding the reaches of the act to discrimination based on sexual orientation and transgender status (see Sharrow, 2020), more traditional-type cases relating to discrimination based on sex have been decided in other contexts interpreting the Equal Pay Act of 1963 and Title IX of the Education Amendments of 1972 in the United States Supreme Court and other federal courts.

How have these decisions impacted the area of athletics - most especially, women's soccer?

\subsection{The Origin of the Debate about Sex Discrimination under the Civil Right Act of 1964}

The origin of the dispute, which the Supreme Court at least partially resolved in Bostock and which permeates many of the cases involving sex discrimination, can be traced to a historic piece of legislation from the 1960's: The Civil Rights Act of 1964 - most especially Title VII—because of the inclusion of the term "sex" in its enumerated categories (Hunter \& Shannon, 2020). From the outset, the inclusion of the term "sex" has proved to be vexing in both context and meaning. The prohibition on sex discrimination found in Title VII was added by Rep. Howard Smith, the powerful Chairman of the House Rules Committee, who strongly opposed the legislation. Smith's amendment to add the word "sex" to the bill was passed by vote of 168 to 133 . However, several historians and others have debated Congressman Smith's real motivation (Osterman, 2009). The Congressional Record indicates that Smith was greeted by laughter when he introduced the one-word amendment (Freeman, 1990).

Was the inclusion of the term "sex" a strategic attempt to defeat the bill by Chairman Smith, or was it a genuine attempt to support women's rights by broadening the bill to include the prohibition against discrimination based on sex? Some historians have speculated that Smith was trying to embarrass Northern Democrats who echoed the position of organized labor and some women's groups who had surprisingly opposed the inclusion of women in the bill because they feared that a new law would take away "protections for pregnant women and women in poverty" already in place (Napikoski, 2020). Others argued that Smith was sincere in his efforts. Napikoski (2020) remarks that Smith had not only sponsored the Equal Rights Amendment in the House of Representatives, but Smith had also been close to the National Woman's Party and its leader Alice Paul.

The inclusion of the term "sex" in the bill under these circumstances may have presaged the comments of Justice William Rehnquist, who explained in Meritor Savings Bank v. Vinson (1986) that the prohibition against discrimination based on sex was added to Title VII at the last minute on the floor of the House of Representatives (see Page 477 U. S. 63). Justice Rehnquist also stated that while the bill quickly passed as amended, we were left with little legislative history to guide us in interpreting the Act's prohibition against discrimination based on "sex" (see Page 477 U. S. 64).

\subsection{Cases Relating to Sex and Gender}

Precisely because of unanswered questions generated by inclusion of the term "sex" in the act itself, the United States Supreme Court has been called upon to decide a large number of cases relating specifically to Title VII. Some of the more important cases include (Find Law, 2017):

- Cleveland Bd. of Ed. v. LaFleur (1974): The Court found that Ohio public schools' mandatory maternity leave rules for pregnant teachers violated constitutional guarantees of due process (Dinner, 2010).

- Meritor Savings Bank v. Vinson (1986): The Court found that a claim of "hostile environment" sexual harassment is a form of sex discrimination that may be brought under Title VII of the Civil Rights Act of 1964 (see Monat \& Gomez, 1986; Dodier, 1987). The case established that the conduct must be "severe and pervasive" in addition to being "unwelcome."

- Johnson v. Transportation Agency (1987): In a case dealing with "affirmative action" on the part of an employer, the Court decided that a county transportation agency appropriately considered an employee's sex as one factor in determining whether she should be promoted (see Adelman, 1987).

- Franklin v. Gwinnett County Public Schools (1992): The Court ruled that students who had been subjected to sexual harassment in public schools may sue for monetary damages (Edmunds, 1993).

- Oncale v. Sundowner Offshore Serv., Inc. (1998): The Court held that sex discrimination consisting of same-sex sexual harassment can form the basis for a valid claim under Title VII of the Civil Rights Act of 1964 (see Brookins, 1998).

- Burlington Industries, Inc. v. Ellerth (1998): The Court held that an employee who refuses the unwelcome and threatening sexual advances of a supervisor (but suffers no real job consequences) may nonetheless recover monetary damages against the employer without showing the employer is at fault for the supervisor's actions 
(Kidder, 1999; Elsenheimer, 2005).

- Faragher v. City of Boca Raton (1998): The Court decided that an employer may be vicariously liable for sexual harassment caused by a supervisor; however, the extent of liability depends on the reasonableness of the employer's conduct, as well as the reasonableness of the alleged victim's conduct in response to the alleged harassment (Faragher, 2005).

Rowan (2018, pp. 929-930) outlines the procedures for filing a complaint under Title VII:

If a plaintiff wishes to bring a cause of action for gender discrimination under Title VII, she cannot go directly to court as the Act does not provide an automatic private right of action. Rather, a plaintiff must first file a claim with the Equal Employment Opportunity Commission (EEOC) within 180 days of the alleged discrimination. After the claim is filed, the EEOC must investigate and determine whether it believes a violation occurred. If the EEOC believes a violation occurred, it may attempt conciliation or file a civil claim against the private employer. However, if the EEOC believes no violation occurred or decides not to pursue litigation, the EEOC must notify the aggrieved party, who has ninety days to file a civil lawsuit on her own.

\section{The Saga of US Women's Soccer and Equal Pay}

The influence of Title IX of the Education Amendments of 1972 on the progress achieved in women's athletics cannot be overstated. Opoien (2019) noted that in 1972, the year Title IX was enacted, just 700 girls in the entire U.S. played high school soccer. By November 1991, when the first women's World Cup was held, that number had increased by more than 17,000\% to 121,722 (Opoien, 2019). In 2018, the National Federation of State High School Associations counted 390,482 girls' soccer players - an increase from 1972 of more than 55,000\%." In 1981 , there were 100 female soccer teams at the collegiate level. Today, there are 1048 teams sponsored by NCAA member schools (NCAA.org, 2021).

In recent years, the players of the U.S. Women's National Team, frequently referred to by the acronym USWNT, have waged an escalating legal battle with the United States Soccer Federation over gender discrimination. Central to their demands is equal pay. As mentioned earlier, the players point to their lower compensation as compared to the U.S. men's national team despite the women's level of success in recent years.

As described by several news outlets (see, for example Chappell, 2016; Das, 2016) five female players from the World Cup-winning U.S. national team accused the U.S. Soccer Federation of wage discrimination in an action filed with the Equal Employment Opportunity Commission on March 31, 2016. Alex Morgan, Carli Lloyd, Megan Rapinoe, Becky Sauerbrunn, and Hope Solo alleged that they were paid nearly four times less than their male counterparts on the U.S. Men's National Team. Das (2016) and Chappell (2016) report that Solo stated that the numbers speak for themselves, particularly that their team was the best in the world with three World Cup Championships and four Olympic Championships. The men's players were paid more just to show up for the games than they received for winning major championships. It is undisputed that the American women have enjoyed far more success "on the pitch" recently than their male counterparts. The furthest the men's team advanced in the World Cup was the 2002 quarterfinals. The men's team failed to qualify for the 2018 World Cup. ESPN.com (2016) reported that at the time of the filing of the lawsuit in 2016, Attorney Jeffrey Kessler, one of the attorneys representing the players, stated his belief that in reality the women's team is more valuable to the USSF than the men's team has been. "That's what the facts show. And they would be justified in asking for more than the men are receiving. But the first step that they are seeking is equal treatment. That should be an easy step for the USSF to take" (ESPN.com, 2016).

The issue has been further complicated because the union representing the players was at the same time involved in a dispute with the United States Soccer Federation (USSF) over the terms of their collective bargaining agreement. The USSF maintained that provisions relating to players' salaries had been collectively bargained and that the agreement would be in force until the completion of the Rio Olympics in the summer of 2016.

What were the facts? The top players on the women's team were paid about $\$ 72,000$ a year by USSF, along with bonuses, to play in a minimum of 20 matches per year - a salary considerably less than their male counterparts. Unlike the men, the women soccer players were awarded bonuses only if they won those matches. Citing another example of the disparity in compensation, the complaint stated that the women were to be paid $\$ 30,000$ each for making the World Cup team, while the men were to be paid $\$ 68,750$. Kilgore (2016) reports that the complaint also stated that there are no legitimate non-discriminatory reasons for the gross disparity of wages, and that it cannot be explained by legitimate reasons for a disparity in wage, such as seniority, merit or incentive system, or any other factor other that sex. 
One year later in April 2017, the women players entered into a new collective bargaining agreement (CBA) with the USSF (McCauley, 2017; Rapp, 2017). The April 2017 agreement provided that the players would receive an increase in their base pay and would receive improved match bonuses. While the changes in the CBA could potentially increase their pay from $\$ 200,000$ to $\$ 300,000$, the CBA did not guarantee the U.S Women's National Team equal pay with the men's team (McCauley, 2017). In addition, U.S. Soccer agreed retroactively to pay the players for two years' worth of unequal per-diem payments. We should note that the CBA's five-year term through 2021 ensured that the next contract negotiations would not affect the team in its upcoming competitions.

\subsection{Issues Relating to Equal Pay Persist}

Haile (2020) reports that on March 8, 2019, all 28 members of the U.S. Women's National Team filed a gender discrimination lawsuit against the U.S. Soccer Federation in the U.S. District Court in Los Angeles. The main allegations in the lawsuit were that the U.S. Soccer Federation had engaged in "institutional gender discrimination," that the Federation had discriminated against the women by paying them less than what it paid the members of the men's national team for substantially equal work and by denying them at least equal playing, training, and travel conditions, equal promotion of their games, equal support and development for their games, and other "terms and conditions of employment" equal to the men's national team (Haile, 2020). Do the players have an "equal pay" issue?

\section{The Equal Pay Act}

The Equal Pay Act of 1963 (EPA), a federal law which amended the Fair Labor Standards Act of 1938, was aimed at abolishing wage disparity based on sex. It was signed into law on June 10, 1963, by President John F. Kennedy as part of his New Frontier Program (Cross, 2014). Section 206(d)(1) of the EPA prohibits employers from discriminating on the basis of sex by paying wages to employees at a rate less than the rate paid to employees of the opposite sex for equal work on jobs requiring equal skill, effort, and responsibility, and which are performed under similar working conditions. There are exemptions, including seniority, merit, and differential based on any other factor other than sex. To establish a prima facie case under the EPA, an employee must show that:

1) Different wages are paid to employees of the opposite sex;

2) The employees perform substantially equal work on jobs requiring equal skill, effort, and responsibility; and

3) The jobs are performed under similar working conditions.

Rowan (2018, pp. 928-929) sums up the requirements for filing an Equal Pay Act cause of action:

In order to have a prima facie case under the Equal Pay Act, the plaintiff has the burden of proving that (1) the jobs held by male and female employees are substantially similar, and (2) the employer is paying different wages to those engaged in this similar work. The plaintiff need not prove that the skills and qualifications of a particular employee are similar to another employee; rather, the job itself must be substantially similar. An ideal case under the Equal Pay Act would require a plaintiff who performs "the same job, for the same employer, with the same responsibilities, having the same experience" as a male counterpart. In order to rebut a claim of discrimination under the Act, a defendant must show that these conditions are not met or prove that the difference is justified by one of the four listed exceptions. It is then up to the court to determine if gender discrimination exists.

The EPA provides that an employer may not pay lower wages to employees of one gender than it pays to employees of the other gender within the same establishment for jobs that require equal skill, effort, and responsibility, and that are performed under similar working conditions under what is known as the Kress Test.

\subsection{Lilly Ledbetter}

Roach (2010) noted that the Supreme Court of the United States has decided several cases which made a revision of the Equal Pay Act necessary. In particular, the controversial decision in in Ledbetter v. Goodyear Tire \& Rubber Co. (2007) made it virtually impossible for a plaintiff to bring a viable Equal Pay claim.

Here is a summary of the case: Goodyear hired Lilly Ledbetter in 1979 to work as a supervisor in Gadsden, Alabama. After working for Goodyear for nineteen years, Ledbetter received an anonymous tip revealing that her pay was thousands of dollars less per year than her male colleagues with similar seniority and experience. This letter led her to file a sex discrimination case against Goodyear. She successfully sued Goodyear after her retirement in November 1998, winning a \$3 million verdict, but the judgment of the trial court was reversed on appeal by the Eleventh Circuit Court of Appeals in 2005. The lawsuit eventually reached the United States Supreme Court, which ruled against her because she had not filed suit within the 180-day period from the date of the discriminatory policy that led to her reduced paycheck. The Supreme Court did not consider the issue of whether 
a plaintiff's late discovery of a discriminatory action would excuse a failure to file within the 180-day period.

In response to the decision of the United States Supreme Court, Congress enacted the Lilly Ledbetter Fair Pay Act of 2009 (Dunn, 2009). The act was signed into law by President Barack Obama in January 2009 (Stolberg, 2009). The act intended to close the pay gap between men and women by resetting the 180-day statute of limitations for equal pay lawsuits with every new paycheck issued. According to Roach (2010), women would be able to bring forth claims of discrimination 180 days after each paycheck. Based on the substance of the Equal Pay Act and the expanded period during which a plaintiff could seek redress, it appears that the women soccer players at least had raised an issue relating to their compensation by the USSF under the criteria of the Kress Test.

\subsection{The USSF Replies}

The USSF defended its practices by noting the difference in the pay structure for the men's and women's teams (Associated Press, 2020; Johnson, 2020). The Associated Press (2020) reported that the USSF argued in documents filed opposing a motion for summary judgment by the players that while pay for both male and female teams is determined by separate collective bargaining agreements reached with the Federation, male players have more responsibility, and this requires a higher level of skill from the men's team than their female counterparts. Johnson (2020) states that in the same filing, the Federation specifically argues that a reasonable juror could conclude that the job of a men's national team player requires materially different skill and more responsibility than any plaintiff's job does. Other points levied by the Federation include (see Robinson, 2020; Johnson, 2020):

- It is not a sexist stereotype to recognize that different levels of speed and strength are required for the two jobs but rather indisputable science that explains why the men have a greater physical ability to compete at their level than the women do at theirs.

- Laws governing equal pay explicitly apply to jobs that require equal skills, and not to employees that possess equal skills. However, the job of an MNT player (competing against senior men's national teams) requires a higher level of skill based on speed and strength than does the job of a WNT player (competing against senior women's national teams).

- The men's team brings in more revenue than does the women's team. The prize money paid to the men's team from winning FIFA-sponsored games far exceeds any amount that the women could receive, even by winning the Women's World Cup. [Prize money for World Cup is set by FIFA, which oversees the global game, and is paid to the winner's federation, not to the players.]

- Television viewership for men's games is higher and that the organization receives more broadcasting revenue from the men's games aired on TV.

- Men's National Team (MNT) players have responsibility for competing in multiple soccer tournaments with the potential for generating a total of more than $\$ 40$ million in prize money for U.S. Soccer every four years. In contrast, Women's National Team (WNT) players compete in only one soccer tournament every four years that has the potential to generate any prize money at all, and most recently that amounted to one-tenth of the amount the MNT players could generate.

- $\quad$ U.S. Soccer is required to pay a $\$ 100,000$ annual salary to a minimum number of WNT Contracted Players each year even if they do not play for the national team. The Federation cited forward Alex Morgan's pregnancy as one example of a player receiving a salary even when she is unable to play. Morgan was receiving $75 \%$ of her salary while on maternity leave.

- Men's team players are paid only when they are called up to play for the men's team.

Booker (2020) reported that the Federation publicly apologized after a backlash against the statements in the court documents, particularly the one that players on the men's national team possess greater skill and have more demanding jobs than their female counterparts. However, the Federation's argument that the job of MNT player facts demonstrate that the job of an MNT player carries more responsibility within U.S. Soccer than the job of a WNT player, is meant to underscore their view that from an Equal Pay Act standpoint, the differential in pay can be legally justified by reference to a factor other than sex. Interestingly, the Federation argued that the women may, in fact, be receiving more compensation than the men because the women's collective bargaining agreement calls for U.S. Soccer to pay $\$ 350,000$ annually to the player's union. According to the filing, money paid to unions is considered "pay" to an employee under the Equal Pay Act.

\subsection{May 2020: Women's Soccer Receives a Setback}

In May of 2020, a federal judge dismissed that part of the equal pay lawsuit brought by the U.S. women's national soccer team that had alleged wage discrimination on the part of the U.S. Soccer Federation (Das, 2020; Hays, 
2020). U.S. District Judge R. Gary Klausner issued a 32-page decision (Morgan v. United States Soccer Federation, 2020) partially granting the Federation's request for summary judgment. He dismissed the Equal Pay Act portion of the lawsuit, but left in the claims regarding the Federation's use of charter flights, hotel accommodations, medical support services and training support services under the Section 703 of the Civil Rights Act of 1964 which states:

(a) It shall be an unlawful employment practice for an employer--

(1) to fail or refuse to hire or to discharge any individual, or otherwise to discriminate against any individual with respect to his compensation, terms, conditions, or privileges of employment, because of such individual's race, color, religion, sex, or national origin; or

(2) to limit, segregate, or classify his employees in any way which would deprive or tend to deprive any individual of employment opportunities or otherwise adversely affect his status as an employee, because of such individual's race, color, religion, sex, or national origin.

(b) It shall be an unlawful employment practice for an employment agency to fail or refuse to refer for employment, or otherwise to discriminate against, any individual because of his race, color, religion, sex, or national origin, or to classify or refer for employment any individual on the basis of his race, color, religion, sex, or national origin.

Judge Klausner largely based his decision on the issue relating to wage discrimination on the collective bargaining agreement entered by union representing the women's national team with the USSF (Rapp, 2017). Judge Klausner points out in his decision that representatives for the players rejected a pay-for-play model identical to the men early in those negotiations in 2016, and that in later negotiations, the players offered a counterproposal with lesser bonuses than the Federation's offer in exchange for more contracted players and higher base salaries. These benefits were not part of the CBA between U.S. Soccer and the men's union. Gerstmann (2020) reports that the court found that the female players received more money than male players on both a cumulative and an average per-game basis. In total, the payments to the female players were approximately $\$ 24$ million and averaged $\$ 220,747$ per game, whereas payments to the male players totaled approximately $\$ 18$ million and averaged $\$ 212,639$ per game. While the female players argued that even though they got paid more than the male players, they would have been paid even more if they were operating under the same contract as the men, Judge Klausner rejected that claim because the men's and women's representatives negotiated different contracts during collective bargaining (Gerstmann, 2020). Judge Klausner indicates in his decision that the women's team was far more risk adverse and bargained for numerous guarantees including a guaranteed minimum salary, injury protections, a minimum number of games played and a guaranteed number of players on the roster. The men's team accepted a great deal of more risk and agreed to terms under which they are only paid for the games they play (or pay to play; See Morgan v. United States Soccer Federation, 2020). As Gerstmann (2020) notes it is because the women's team players were so successful that they would have made more money under the men's arrangement, except that they did not want to take the risk that their playing would not be as successful.

We want to underscore a final point in Judge Klausner's decision: The plaintiffs, the USWNT, cannot now retroactively deem their CBA worse than the MNT's CBA by reference to what they would have made had they been paid under the MNT's pay-to-play terms structure when they themselves rejected such a structure. In his opinion, then, the women's team was paid under the structure the women players had demanded and negotiated in the 2017 collective bargaining agreement that offered more benefits and guarantees than those found in the contract the men had negotiated. The benefits and guarantees included guaranteed annual salaries, medical and dental insurance, paid child-care assistance, paid pregnancy and parental leave, and severance benefits.

\subsection{A Tentative Settlement of Issues under the Civil Rights Act-But Not as to the Equal Pay Issue}

By December 2020, the U.S. Soccer Federation appeared to have reached a settlement with the Women's National Team over working conditions, but the dispute over equal pay remained unresolved (Close, Martin \& Asmelash, 2020). The agreement filed in the U.S. District Court for the Central District of California on December 1, 2020, was a partial victory for the U.S. women's soccer team. Players on the Women's National Team will see an improvement in hotel accommodations, venues, travel and staffing that will put them on equal footing with players on the Men's National Team (Madani, 2020).

Interestingly, Romo (2020) states that among the most notable changes reached in the settlement is a requirement that matches be played on grass in almost all circumstances, adding that the women's team has been fighting for years to end matches played on artificial surfaces while the men's team rarely had to contend with this condition. This was a major issue to the women players because of the increased possibility of injury to the players (Murray, 
2017). The Federation will also provide an equal number of chartered flights to the women's and men's teams and agreed to offer comparable hotel accommodations for the teams as well. As reported by Romo (2020), the women will also have comparable staff with 18 to 21 professional positions to provide support services to the respective teams.

Would this end the controversy? According to Long (2020) a spokesman for the women who filed the suit against the USSF stated that the next steps include filing an appeal to the Court's decision which does not account for the equal pay issue. The settlement was approved by a California federal judge on April 12, 2021, thus resolving the working conditions issue. A final judgment must still be entered on the equal pay claims, in order for the WNT to file an appeal.

\section{But... Could There Still be a Title IX Problem?}

Title IX of the Education Amendments of 1972 was enacted on June 23, 1972. In 2002, it was renamed the Patsy T. Mink Equal Opportunity in Education Act, in honor of its principal author Congresswoman Mink, but it is most commonly known simply as Title IX (Women's Sports Foundation, 2021). Title IX states that:

No person in the United States shall, on the basis of sex, be excluded from participation in, be denied the benefits of, or be subjected to discrimination under any education program or activity receiving Federal financial assistance.

What was the impetus for enacting Title IX? Villalobos (1990, p. 154) points out the following: "In the latter part of the 1970s and early 1980s, leadership opportunities for women had diminished and women's participation in intercollegiate athletics had come to a standstill." In addition, Villalobos (1990) states that the 1970s and 1980s left an uphill struggle for women in the future and may be characterized by the following:

- For financial aid based on athletic ability approximately one dollar in five is awarded to women.

- Men coach fifty percent of the women's teams.

- Only fifteen percent of women's intercollegiate programs are under the supervision of female athletic directors.

- Only one of the NCAA Division I merged athletic programs in the United States has a woman as the athletic director.

- The highest paid college women's basketball coach in 1986-87 earned sixty-one percent less than the highest paid men's basketball coach.

- In 1986-87, the four highest paid coaches in women's basketball were men.

- Only thirty-one percent of the 1985-86 NCAA participants were female.

- Currently, there are fewer women's national championships, in fewer sports and in fewer divisions, than there were in 1981-82.

Although Title IX is best known for its impact on high school (Stevenson, 2007) and collegiate athletics (Gerstmann, 2020), the original statute made no explicit mention of sports (Chamberlain, Cornett, \& Yohanan, 2018). Brake (2000/2001) notes that the changes in women's sports have been followed by increased status and respect for female athletes and a growing enthusiasm for women's sports in popular culture, driven mostly by recent public successes of elite female athletes.

The legislation covers all educational programs and activities in which there is an allegation of sex discrimination and also applies to non-sport activities such as school bands and clubs. However, social fraternities and sororities, sex-specific youth clubs such as Girl Scouts and Boy Scouts, Girls State and Boys State, and admission policies for private college (Lew, 2021) are specifically exempt from Title IX requirements.

Title IX is administered by the Office for Civil Rights in the U.S. Department of Education (OCR). A controversy was created because of an interpretation of Title IX that was announced by the Supreme Court in Grove City v. Bell (1984). 
Grove City College is a private, church-affiliated, co-educational institution of higher education in Grove City, a small town in northwestern Pennsylvania. Since its founding in the 19th Century, the college had refused to accept directly any forms of government assistance on grounds that compliance with the rules that accompany such assistance would compromise its independence and ability to deliver high-quality education at low cost.

In July 1976, the Executive Branch department, now known as the Department of Education, required the college to file an assurance of compliance stating that it was following the Title IX regulations prohibiting discriminating on the basis of gender. The directive was based, in part, on the fact that 140 of the college's approximately 2,200 students received direct grants through the federal government's Basic Educational Opportunity Grant (BEOG) program.

The college refused to comply with this request on grounds that it did not receive federal financial assistance. As a result, the department initiated formal proceedings to terminate the students' BEOGs. After a hearing, an administrative law judge decided that because the college received federal assistance, it was required under Title IX to file an assurance of compliance report. The college's refusal was sufficient grounds for the department to prohibit its grants to the students.

The case reached the United States Supreme Court.

A 6-3 majority of the Court held that when students receive federally funded grants, Title IX requirements only apply to the specific program or activity that was benefitted by the grants. In such instances, Title IX requirements do not apply across the entire institution.

Congress responded by enacting the Civil Rights Restoration Act of 1988, also known as the Grove City Bill, that specified that recipients of federal funds must comply with anti-discrimination laws in all areas of their operations, not just in the program or activity that received the federal funding (see Weldon, 1990). The final vote in the United States Senate on January 28, 1988, was 75-14, while the final vote in the House of Representatives on March 2, 1988, was 315-98. On March 16, 1988, President Ronald Reagan vetoed the bill. On March 22, 1988, the Senate overrode Reagan's veto by a vote of 73-24, with the House concurring on the same day by a vote of 292-133.

President Reagan's veto was the first veto of a civil rights act since President Andrew Johnson had vetoed the Civil Rights Act of 1866 (Curry, 1988; Marcus \& Dewar, 1988). The 1988 statute applies to Title IX of the Education Amendments of 1972, the 1973 Rehabilitation Act, Title VI of the Civil Rights Act of 1964, and the Age Discrimination in Employment Act.

Villalobos (1990) notes that the OCR determines whether the equivalent treatment, benefits, and opportunities mandated by Title IX have been afforded to both women and men based on the data they collect. According to Villalobos, a finding of inequality in a single component of the program is not enough for the OCR to find a school in noncompliance with Title IX. The Department of Education evaluates the following factors in determining whether equal treatment exists with specific reference to athletic programs:

(1) Whether the selection of sports and levels of competition effectively accommodate the interests and abilities of members of both sexes;

(2) The provision of equipment and supplies;

(3) Scheduling of games and practice time;

(4) Travel and per diem allowance;

(5) Opportunity to receive coaching and academic tutoring on mathematics only;

(6) Assignment and compensation of coaches and tutors;

(7) Provision of locker rooms, practice and competitive facilities;

(8) Provision of medical and training facilities and services;

(9) Provision of housing and dining facilities and services;

(10) Publicity. 
Unequal aggregate expenditures for members of each sex or unequal expenditures for male and female teams if a recipient operates or sponsors separate teams will not necessarily constitute noncompliance with this section. But the Office for Civil Rights, as the responsible party for enforcement of Title IX, may consider the failure to provide necessary funds for teams for one sex in assessing equality of opportunity for members of each sex, a core requirement under Title IX.

\subsection{Three-prong Test of Compliance}

In 1979, the U.S. Department of Health, Education, and Welfare under President Jimmy Carter issued a policy interpretation for Title IX, including what has become known as the "three-prong test" to assess an institution's compliance with the statute (see Anderson, Cheslock, Ehrenberg, 2016).

- Prong one - Providing athletic participation opportunities that are substantially proportionate to the student enrollment, OR

- Prong two - Demonstrate a continual expansion of athletic opportunities for the underrepresented sex, OR

- Prong three - Full and effective accommodation of the interest and ability of underrepresented sex.

A recipient of federal funds can demonstrate compliance with Title IX by meeting any one of the three prongs.

On March 17, 2005, the Office for Civil Rights (OCR) under President George W. Bush announced a clarification of prong three of the three-part test of Title IX compliance. The guidance concerned the use of certain web-based surveys to determine the level of interest in varsity athletics among the under-represented sex (see Preussel, 2006; Buzuvis, 2006). However, on April 20, 2010, the OCR, under President Barack Obama, essentially overturned the 2005 clarification that allowed institutions to use only Internet or e-mail surveys to measure the interests and abilities (third prong) option of the three-part test for Title IX compliance (Somin, 2010). Opponents of the 2005 clarification-including the NCAA Executive Committee, which issued a resolution soon afterward asking Association members not to use the survey, claimed the survey was flawed in part because of the way it counted non-responses. Gualtieri $(2020$, p. 207) reported that "small baccalaureate colleges are more likely to include references to the law in their formal documents than their research university peers do."

The last major piece of Title IX legislation was the passage of the Equity in Athletics Disclosure Act of 1994 (see Brown, 2000). The act, sponsored by Illinois Congresswoman Cardiss Collins, requires federally-assisted higher education institutions to disclose information on roster sizes for men's and women's teams, as well as budgets for recruiting, scholarships, coaches' salaries, and other expenses, annually. This provides for much more accurate monitoring of Title IX compliance (see Maimer, Bergeron, Bosetti, \& Teed, 2003).

Since Title IX was enacted into law, there have been many cases alleging non-compliance. One of the most notable cases is Franklin vs. Gwinnett County (1992). The court determined that damages may be awarded to plaintiffs when the mandates of Title IX are intentionally avoided or violated. One year later in Favia vs Indiana University of Pennsylvania (1993), the Third Circuit Court of Appeals ruled that financial difficulties are not an excuse for non-compliance when the defendant-university refused to reinstate its women's field hockey and gymnastics programs.

In another instance of non-compliance with Title IX involving Louisiana State University, a federal court referenced Title IX in ruling that LSU had violated the civil rights of female athletes with "arrogant ignorance" of their needs, although the women will receive no money because the violation was not deemed intentional (Coates, 1996). The judge in the case noted that LSU's approach suggests ignorance of the changed social fabric in this country and that LSU's outmoded approach to athletics includes antiquated assumptions about women's athletic interests and abilities (Coates, 1996). Since this ruling, it was thought that LSU had made substantial changes in its athletic programs to achieve compliance - that is, until a new set of allegations surfaced in 2020 relating to domestic and sexual violence on campus (see LSU, 2021; Gremillion, 2021). Subsequent to a report issued by the firm Husch Blackwell, LSU agreed to add a new office of Civil Rights and Title IX to its administrative organizational structure.

\subsection{Participation}

Title IX has impacted female participation in both high school (Stevenson, 2007) and college athletics (Gerstmann, 2020). According to the National Federation of State High School Associations (NFHS.org), in 1972, the year Title IX was passed, just 700 girls in the entire U.S. played high school soccer. By 1991, when the first women's World Cup was held, that number had increased by more than 17,000\% to 121,722 (NFHS.org). In 2018-19, the National Federation of State High School Associations (NFHS) counted 394,105 girls soccer players - an increase from 1972 of more than $55,000 \%$. Table 1 shows the numbers and percentage increase in girls' sports on the high school 
level from 2008 through 2019.

Table 1. NFHS girls sports participation, 2008-09 to 2018-19 (NFHS, 2009, 2019)

\begin{tabular}{lrrrr}
\hline Sport & $\begin{array}{c}\text { 2008-09 Girls } \\
\text { Participation }\end{array}$ & $\begin{array}{l}\text { 2018-19 Girls } \\
\text { Participation }\end{array}$ & $\begin{array}{l}\text { Numeric } \\
\text { Change }\end{array}$ & \multicolumn{2}{l}{$\begin{array}{l}\text { Percentage } \\
\text { Change }\end{array}$} \\
\hline Outdoor Track \& Field & 457,732 & 488,267 & 30,535 & $6.7 \%$ \\
Volleyball & 404,243 & 452,808 & 48,565 & $12.0 \%$ \\
Basketball & 444,809 & 399,067 & $(45,742)$ & $-10.3 \%$ \\
Soccer & $\mathbf{3 4 4 , 5 3 4}$ & $\mathbf{3 9 4 , 1 0 5}$ & $\mathbf{4 9 , 5 7 1}$ & $\mathbf{1 4 . 4 \%}$ \\
Softball, Fast-Pitch & 368,921 & 362,038 & $(6,883)$ & $-1.9 \%$ \\
Cross Country & 198,199 & 219,345 & 21,146 & $10.7 \%$ \\
Tennis & 177,593 & 189,436 & 11,843 & $6.7 \%$ \\
Swimming \& Diving & 158,878 & 173,088 & 14,210 & $8.9 \%$ \\
Competitive Spirit & 177,936 & 161,358 & $(16,578)$ & $-9.3 \%$ \\
Lacrosse & 64,929 & 99,750 & 34,821 & $53.6 \%$ \\
\hline
\end{tabular}

Beene (2019) notes, "Title IX's monumental influence on women's athletics cannot be overstated" (see also GAO, 2019). In 1981, there were 100 female soccer teams at the collegiate level. Today, there are 1048 teams competing in NCAA Decision I, II, and III (NCAA.org, 2021). In addition, there are 188 women's teams that compete in the NAIA, or National Association of Intercollegiate Athletics (NAIA.org, 2021). Gerstmann (2020) writes:

There's been an explosion of women in athletics since the passage of Title IX. And particularly for women's sports, and it's had a worldwide effect. According to data from the NCAA, all but nine of the 24 teams competing at the World Cup contain current or former player who played US college soccer. That includes three teams - US, Canada and Jamaica — where most of the roster competed at a US school.

Meredith (2017) provides a prescient commentary on the status of men's and women's athletics on the collegiate level:

Spending on men's and women's athletic programs has doubled over the past decade across all three NCAA divisions and the greatest gap between the two can be found in Division I, according to a report released Wednesday marking the 45th anniversary of the Title IX ruling that bars discrimination based on gender.

The 60-page report, released by the NCAA, suggests some progress has been made in a number of areas when it comes to participation, diversity and equality among college athletes, their coaches and their athletic directors. But it also found stark gaps remain even as spending has climbed to record levels.

Division I athletic departments spend on average about twice as much on their men's programs than their women's programs, though schools without football spend nearly the same on each (about $\$ 5$ million).

The report said the difference was even greater among schools in the top-tier Football Bowl Subdivision, which spent an average of \$27.3 million on men's sports in 2015 - up from \$12.8 million in 2005 — and an average of $\$ 45,000$ more on male athletes than women in 2015. The average spending on women's teams at FBS schools went from $\$ 5.5$ million to $\$ 10.5$ million during that same span.

Much of that money is dedicated to the gridiron, with FBS schools dedicating 60 percent of their men's athletic budget on football - three times as much as men's basketball.

According to the report, 330 Division I men's teams have been cut while 803 women's team were added since 1988. No details are included, but scores of wrestling, men's tennis and men's gymnastics programs have been dropped over the past 30 years. The University of Buffalo recently booted men's soccer, men's swimming and diving, and baseball in a cost-cutting move. In 2011, California's baseball team was forced to raise $\$ 9$ million in donations to avoid being dropped. 
The NCAA said male and female athletes continue to set participation records each year. From 2002-2016, male athletes gained some 65,000 "participation opportunities" and female athletes almost 58,000. Men still make up 56.5 percent of all college athletes across all three divisions.

Since 1982, the year the NCAA began sponsoring women's championship sports, participation by women in athletics has gone from just under 30 percent in Division 1 to 46.7 percent in 2016. The NCAA also said female athletes across all NCAA divisions are more racially and ethnically diverse than they were in 200001.

Schools with an FBS program spend 44 percent of their budget on men's teams compared with just 18 percent for women's teams. The report also found that FBS schools spend 75 percent of their coaching compensation budgets on men and 70 percent on recruiting dollars on men's teams. Though the disparity is smaller in FCS - 41 percent spending on men's teams to 26 percent on women's teams - it's clear that football has a major impact on spending equality. Division I schools that don't sponsor football spend almost equal amounts, with men getting 35 percent of the budget and women 32 percent.

\section{Observations and Recommendations}

There are numerous legal and factual impediments to applying Title IX to the current controversy between the United States National Team and the United States Soccer Federation. Because of the language of Title IX itself, there is doubt whether Title IX facially applies to the U.S. Soccer Federation. The USSF is not an "educational program or activity" referenced in the statute. In addition, the great majority of the USSF's funding is not federal, which makes the legislation sponsored in the House of Representatives by Congressmen DeLauro and Matsui and by Senator Manchin in the Senate (Kelly, 2019) much less threatening. Rather, most of the funding comes from long-term corporate sponsorships such as Nike.

According to Draper (2019), the USSF anticipates approximately \$20 million in sponsorship revenue, including $\$ 4$ million from Nike designated specifically for player development. However, Draper (2019) also reported that Nike emphasized its broad support of women's soccer (It sponsored 14 of the 24 teams in the recent World Cup.) and of women's sports in general. Nike has also supported equal pay for of the women's team (Draper 2019). Additional sponsors include VW, Allstate, Chipotle, AT\&T, Deloitte, BIO Steel, GOGO Squeez, Anheuser-Busch, and Visa.

Haile (2020) reports that on the international level the prize money for the 2022 Men's World Cup is budgeted to be $\$ 440$ million. Following the success of the 2019 Women's World Cup, FIFA President Gianni Infantino proposed expanding the field from twenty-four to thirty-two teams and doubling the prize money (Hays, 2019). FIFA subsequently approved the increase in the number of Women's World Cup participants (FIFA, 2019). FIFA has not yet officially acted on the proposed prize money increase. The Federation should use its influence to support a significant increase in the prize money for the women's tournament so that FIFA can fulfill its stated objective of promoting the development of women's football and the full participation of women at all levels of football governance (FIFA Women's Football Convention, 2019).

What, then, might be the most practical course of action for US Women's Soccer? Here are some recommendations. First, continue to put pressure on the USSF to "do the right thing" even if there is not a legal requirement under either the Equal Pay Act or Title IX to equalize the compensation of men's and women's soccer players. Second, request FIFA to require all participatory countries' men's and women's soccer teams to have equal pay in order to play in any FIFA sponsored tournaments and competitions. Third, request FIFA to have the same number of men's and women's tournaments and competitions. Fourth, concentrate on the collective bargaining process to resolve issues relating to the equalization of salaries between men and women who compete on the U.S. national teams. Finally, emphasize a dynamic marketing strategy that highlights the successes of the U.S. Women's National Team to maximize public pressure on the USSF. Couple this with approaching its corporate sponsors and engaging them as allies on the issue of equal pay for these extraordinarily accomplished and talented athletes, especially during the next round of international competitions.

A more sweeping and long-lasting approach would be to continue to lobby the U.S. Congress to remove the time limit on the Equal Rights Amendment's ratification process and declare it complete when three-fourths (38) of the states ratify. This would mean retaining the existing 35 state ratifications as viable and focusing on three more 
states. While putting the Equal Rights Amendment back on the table may be a feasible step to pass it, we are unsure how long this process would take. Adding to the timeline is the fact that additional laws would be necessary to implement a process that would ensure the contained protections. However, this is a topic for discussion elsewhere, but it may affect the future negotiations between the players and the USSF.

\section{References}

Adelman, R. W. (1987). Voluntary affirmative action plans by public employers: the disparity in standards between Title VII and the equal protection clause. Fordham Law Review, 56, 403-430.

Age Discrimination in Employment Act of 1967. 29 U.S.C. Section 621-634.

Americans with Disabilities Act of 1990. 42 U.S.C. Section 12101.

Anderson, D. J., Cheslock, J. J., \& Ehrenberg, R. G. (2016). Gender equity in intercollegiate athletics: determinants of Title IX compliance. The Journal of Higher Education, 77(2), 225-250. https://doi.org/10.1353/jhe.2006.0010

Associated Press. (2020). US Soccer says male players have more responsibility because of hostile crowds. The New York Post (March 11). Retrieved from https://nypost.com/2020/03/11/us-soccer-says-male-players-havemore-responsibility-because-of-hostile-crowds/

Attitude Express, Inc. v. Zarda. (2020). 590 U.S.__ , 140 S. Ct. 1732 (United States Supreme Court).

Beene, C. P. (2019). Title IX reflections for the women's world cup. Sports History Weekly. Retrieved from http://sportshistoryweekly.com/stories/title-ix-college-team-usa-soccer-women-world-cup-brandichastain, 732.html

Booker, B. (2020). U.S. Soccer Apologizes for Saying Male Players Have 'More Responsibility' Than Women. NPR.org (March 11). Retrieved from https://www.npr.org/2020/03/11/814656567/male-players-have-moreresponsibility-than-women-u-s-soccer-says-in-court-filing

Bostock v. Clayton County, Georgia (2020). 590 U.S. 140 S. Ct. 1731 (United States Supreme Court).

Brake, D. (2000-2001). The struggle for sex equality in sport and the theory behind Title IX. University of Michigan Journal of Law Reform, 34, 13-149.

Brookins, R. (1998). A rose by any other name... the gender basis of same-sex sexual harassment. Drake Law Review, 46, 441-538.

Brown, D. (2000). Equity in Athletics Disclosure Act. Notre Dame News. Retrieved from https://news.nd.edu/news/equity-in-athletics-disclosure-act/

Burlington Industries, Inc. v. Ellerth (1998). 524 U.S. 742 (United States Supreme Court).

Buzuvis, E. E. (2006). Survey says... a critical analysis of the new Title IX policy and a proposal for reform. Iowa Law Review, 91, 821-883.

Carter, K. (2020). Questioning the definition of "sex" in Title VII: Bostock v. Clayton County, Ga. Duke Journal of Constitutional Law and Public Policy Sidebar, 15, 59-75.

Chamberlain, E., Cornett, H., \& Yohanan, A. (2018). Athletics and Title IX of the Education Amendments. Georgetown Journal of Gender and Law, 19, 231-263.

Chappell, B. (2016). U.S. Women's Soccer Team Members File Federal Equal-Pay Complaint. NPR.org (March 31). Retrieved from https://www.npr.org/sections/thetwo-way/2016/03/31/472522790/members-of-u-swomen-s-national-team-file-federal-equal-pay-complaint

Civil Rights Act of 1866. 14 Stat. 27-30.

Civil Rights Act of 1964. Public Law 88-352, 78 U.S. Statutes 241.

Civil Rights Act of 1991. Public Law 102-166.

Civil Rights Restoration Act of 1987. Public Law 100-259.

Cleveland Bd. of Ed. v. LaFleur (1974). 414 U.S. 632 (United States Supreme Court).

Close, D., Martin, J., \& Asmelash, L. (2020). US Soccer reaches deal with women's national team in fight for equal working conditions, but not equal pay. CNN.com (December 1). Retrieved from https://www.cnn.com/2020/ 12/01/us/uswnt-us-soccer-deal-working-conditions-trnd-spt/index.html

Coates, G. (1996). Court rules that LSU violated Title IX. Associated Press News. Retrieved from 
https://apnews.com/article/68b46530607188008ebf9876864736a.

Cross, S. (2014). The Equal Pay Act, fifty years on. Nova Publishers: Hauppauge, N.Y.

Curry, G. E. (1988). Reagan vetoes civil rights bill. Chicago Tribune (March 17). Retrieved from https:/www.chicagotribune.com/news/ct-xpm-1988-03-17-8803010367-story.html.

Das, A. (2016). Top female players accuse U.S. soccer of wage discrimination. The New York Times (March 31). Retrieved from https://www.nytimes.com/2016/04/01/sports/soccer/uswnt-us-women-carli-lloyd-alexmorgan-hope-solo-complain.html

Das, A. (2020). U.S. Women's Soccer Team's Equal Pay Demands Are Dismissed by Judge. The New York Times (May 1). Retrieved from https://www.nytimes.com/2020/05/01/sports/soccer/uswnt-equal-pay.html

Dinner, D. (2010). Recovering the LaFleur doctrine. Yale Journal of Law and Feminism, 22, 343-406.

Dodier, G. (1987). Meritor Savings Bank v. Vinson: sexual harassment at work. Harvard Women's Law Journal, 10, 203-221.

Draper, K. (2019). Pushed by consumers, some sponsors join soccer's fight over equal pay. The New York Times (August 5). Retrieved from https://www.nytimes.com/2019/08/05/sports/soccer/womens-soccer-nikesponsors.html

Dunn, B.C. (2009). Lilly Ledbetter Act extends time for filing fair pay claims. Virginia Lawyer, 57, $25-26,57$.

Edmunds, K.W. (1993). Implying damages under the Individuals with Disabilities Education Act: Franklin v. Gwinnett County Public Schools adds new fuel to the argument. Georgia Law Review, 27, 789-848.

Education Amendments of 1972 [Title IX]. Public Law 92-318, 86 Stat. 235.

Elsenheimer, A. G. (2005). Agency and liability in sexual harassment law: toward a broader definition of tangible employment actions. American University Law Review, 54, 1635-1669.

Equal Pay Act of 1963. Public Law 88-38.

Equity in Athletics Disclosure Act of 1994. 20 U.S.C. Section 1092.

ESPN (2016). U.S. women's team files wage-discrimination action vs. U.S. soccer. ESPN.com news service (March 31). Retrieved from https://abcnews.go.com/Sports/us-women-team-files-wage-discriminationaction-us/story?id=38051286

Fair Labor Standards Act of 1938. 29 U.S.C. Section 203.

Faragher v. City of Boca Raton. (1998). 574 U.S. 775 (United States Supreme Court).

Faragher, B. A. (2005). The 40th anniversary of Title VII of the Civil Rights Act of 1964 symposium: Faragher v. City of Boca Raton: a personal account of a sexual discrimination plaintiff. Hofstra Labor and Employment Law Journal, 22, 417-429.

Favia v. Indiana University of Pennsylvania (1993). 7 F.3d 332 (United States Circuit Court for the Third Circuit).

FIFA Women's Football Convention. (2019). Retrieved from https://img.fifa.com/image/upload/ m7ocddzbwyocx56tcall.pdf

FIFA. (2019). FIFA Council unanimously approves expanded 32-team field for FIFA Women's World Cup. FIFA.com (July 31). Retrieved from https:/www.fifa.com/womensworldcup/news/fifa-council-unanimouslyapproves-the-expansion-of-the-fifa-women-s-world-cup-to

Find Law (2017). Civil rights: U.S. Supreme Court decisions (July 26). Retrieved from https:/civilrights.findlaw.com/ civil-rights-overview/civil-rights-u-s-supreme-court-decisions.html

Franklin v. Gwinnett County Public Schools. (1992). 503 U.S. 60 (United States Supreme Court).

Freeman, J. (1990). How sex got into Title VII: persistent opportunism as a maker of public policy. Law and Inequality, 9, 163-184.

Gerstmann, E. (2020). This is why the U.S. women's soccer team lost its pay discrimination suit. Forbes (May 4). Retrieved from https:/www.forbes.com/sites/evangerstmann/2020/05/04/this-is-why-the-us-womenssoccer-team-lost-their-pay-discrimination-suit/

Give Our Athletes Level Salaries (GOALS) Act. (2020-2021). H.R. 3917.

Government Accountability Office (GAO). (2010). Title IX and high school sports: facts and findings. GAO.gov (February 6). Retrieved from https://blog.goa.gov/2019/02/06/title-ix-and-high-school-sports-facts-and- 
findings/

Gremillion, N. (2021). LSU releases action plan to improve response to sexual misconduct allegations. KPLCTV.com (March 17). Retrieved from https://www.kplctv.com/2021/03/17/Lsu-releases-action-planimprove-response-sexual-misconduct-allegations/

Grove City v. Bell (1984). 465 U.S. 555 (United States Supreme Court).

Gualtieri, G. (2020). Symbolic compliance and student concerns: legal endogeneity and Title IX at American colleges and universities. Sociological Forum, 35(1), 207-228. https://doi.org/10.1111/socf.12574

Haile, A. J. (2020). An even playing field: the goal of gender equity in world cup soccer. Oregon Law Review, 98, 427-475. https://doi.org/10.2139/ssrn.3443799

Harris v. Equal Employment Opportunity Commission. (2020). 590 U.S. , 140 S. Ct. 1731 (United States Supreme Court).

Hays, G. (2019). FIFA plans to expand WWC, double prize money. ESPN.com (July 5). Retrieved from https://www.espn.com/soccer/blog-fifa/story/3893551/fifa-plans-to-expand-wwcdouble-prize-money

Hays, G. (2020). Judge sides with U.S. Soccer in USWNT's equal pay lawsuit. ESPN.com (May 1). Retrieved from https://www.espn.com/espnw/sports/story/_id/29125363/judge-sides-us-soccer-uswnt-equal-pay-lawsuit

Hunter, R. J., \& Shannon, J. (2020). The Civil Rights Act of 1964: beyond race to employment discrimination based on sex: the "three letter word" that has continued to vex society and the United States Supreme Court. The Journal of Social and Political Sciences, 3(3), 613-636. https://doi.org/10.31014/aior.1991.03.03.196

Johnson v. Transportation Agency. (1987). 480 U.S. 616 (United States Supreme Court).

Johnson, L. M. (2020). US soccer claims it won't pay women equally because being a male player requires more skill. CNN.com (March 12). Retrieved from https://www.cnn.com/2020/03/11/us/us-soccer-federation-courtdocument-tmd.index.html

Kelly, C. (2019). Senate democrat wants to halt federal 2026 world cup funding until USWNT receives equal pay. CNN.com (Politics). Retrieved from https://www.foxcarolina.com/sports/senate-democrat-wants-to-haltfederal-2026-world-cup-funding-until-uswnt-receives-equal-pay/article_42cad96b-a35e-5768-b957087 fcflebela.html

Kidder, R. W. (1999). A conciliatory approach to workplace harassment: Burlington Industries, Inc. v. Ellerth and Faragher v. City of Boca Raton. Houston Law Review, 36, 1315-1369.

Kilgore, A. (2016). U.S. women's soccer players raise stakes in debate over how pay scales are set. The Washington Post (March 31). Retrieved from https://www.washingtonpost.com/sports/dcunited/us-womens-soccerplayers-raise-stakes-in-debate-over-how-pay-scales-are-set/2016/03/31/31f65efa-f763-11e5-a3cef06b5ba21f33_story.html

Ledbetter v. Goodyear Tire \& Rubber Co. (2007). 550 US. 618 (United States Supreme Court).

Legault, M., Pasternak, D., Lawless, L., \& Clark L. (2020). Landmark U.S. Supreme Court Ruling Prohibits Sexual Orientation and Gender Identity-Based Discrimination in Employment (US) (June 15). Retrieved from https://www.employmentlawworldview.com/landmark-u-s-supreme-court-ruling-prohibits-sexualorientation- and-gender-identity-based-discrimination-in-employment-us/

Lew, K. (2021). Unbalanced: the case for removing Title IX's private college admissions exemption. Duke Law Journal, 40, 847-883.

Lilly Ledbetter Fair Pay Act of 2009. Public Law 111-2, 123 Stat. 5.

Long, M. (2020). US soccer and USWNT reach settlement but equal pay dispute rumbles on. Sports Promedia (December 2). Retrieved from https://www.sportspromedia.com/news/us-soccer-usnwt-settlement-equalpay-dispute

LSU (2021). Title IX review. LSU.edu. (March 24). Retrieved from https://www.Lsu.edu/titleix-review/

Macias, Jr., M. (2021). Judge Approves US Women's Soccer Settlement on Working Conditions. Courthouse News Service (April 12). Retrieved from https://www.courthousenews.com/judge-approves-us-womens-soccerteams-settlement-on-working-conditions/

Madani, D. (2020). U.S. Soccer reaches settlement with World Cup women's team on work conditions - but not pay. NBCNews.com (December 1). Retrieved from https://www.nbcnews.com/news/sports/u-s-soccer- 
reaches-settlement-world-cup-women-s-team-n1249603

Maimer, P. J., Bergeron, D., Bosetti, H., \& Teed, K. (2003). Title IX at thirty: Equity in Athletics Disclosure Act (EADA): proportionality, revenue, expense, and opportunity for women and men. Sport Management and Free Communications: Investigating Gender Issues in Sport (Conference) (April 3). Retrieved from https://aahperd.confex.com/aahperd/2003/finalprogram/paper_4045.htm

Marcus, R., \& Dewar, H. (1988). Reagan vetoes Civil Rights Restoration Act. The Washington Post (March 17). Retrieved from https://www.washingtonpost.com/archive/politics/1988/03/17/reagan-vetoes-civil-rightsrestoration -act/ 652d878e-b429-49e0-9933-54e38bdlebf0/

McCauley, K. (2017). USWNT CBA a victory for all American women's soccer players, not just the best ones. SBNation.com (April 5). Retrieved from https://www.sbnation.com/soccer/2017/4/5/15190488/uswnt-cbadeal-united-states-national-team-usa-womens-soccer

Meredith, L. (2017). NCAA Title IX report: spending up, gender gap remains. The Seattle Times (June 21). Retrieved from https://www.seattletimes.com/sports/ncaa-title-ix-report-spending-up-gender-gaps-remain/

Meritor Savings Bank v. Vinson. (1986). 477 U.S. 57 (United States Supreme Court).

Monat, J. S., \& Gomez, A. (1986). Sexual harassment: the impact of Meritor Savings v. Vinson on grievances and arbitration decisions. Arbitration Journal, 41(4), 24-29.

Morgan v. U.S. Soccer Fed'n, Inc., 445 F. Supp. 3d 635 (C.D. Cal. 2020).

Morgan v. United States Soccer Federation, Inc. (2019). 2019 U.S. Dist. LEXIS 221602 (United States District Court for the Central District of California).

Murray, C. (2017). New turf fight has U.S. soccer and women's team at odds again. The New York Times (September 21). Retrieved from https://www.nytimes.com/2017/09/21/sports/soccer /uswnt-us-soccerartificial-turf.html

NAIA.org (last accessed April 4).

Napikowski, L. (2020). How women became part of the 1964 Civil Rights Act. Thought Co. (February 4). Retrieved from https://www.thoughtco.com/women-and-the-civil-rights-act-3529477

National Federation of State High School Associations (NSFH) (2009). High School Athletics Participation Survey Data 2008-09. Data may be downloaded from https://members.nfhs.org/participation_statistics

National Federation of State High School Associations (NSFH). (2019). High School Athletics Participation Survey 2018-19. Retrieved from https://www.nfhs.org/media/1020412/2018-19_participation_survey.pdf

NCAA.org. List of NCAA Division 1, Division II, and Division III Men's soccer programs. (last accessed April 2, 2021).

NCAA.org. List of NCAA Division 1, Division II, and Division III Women's soccer programs. (last accessed April 2, 2021).

NCSASPORTS.org. Complete list of NAIA colleges with men's soccer teams. (last accessed April 2, 2021).

NCSASPORTS.org. Complete list of NAIA colleges with women's soccer teams. (last accessed April 2, 2021).

NFHS.org. Girls' Sports Participation. Retrieved from https://members.nfhs.org/participation_statistics (Last accessed April 5, 2021).

Oncale v. Sundowner Offshore Serv., Inc. (1998). 523 U.S. 76 (United States Supreme Court).

Opoien, J. (2019). Title IX paved the way for U.S. soccer dominance, but the work isn't done. The Capital Times (July 15). Retrieved from https://madison.com/ct/opinion/column/jessie-opoien-title-ix-paved-the-way-foru-s-soccer-dominance-but-the-work/article_fe9e8fd4-5deb-57dd-8421-9f1b80ac680d.html

Osterman, R. (2009). Origins of a myth: why courts, scholars, and the public think Title VII's ban on sex discrimination was an accident. Yale Journal of Law and Feminism, 20, 409-440.

Preussel, R. M. (2006). Successful challenge, ruling reversed: why the Office of Civil Rights' survey proposal may be well-intentioned but misguided. Sports Law Journal, 13, 79-132.

Rapp, T. (2017). U.S. women's soccer team agrees to new CBA with U.S. soccer after labor dispute. Bleacher Report (World Football) (April 5). Retrieved from https://bleacherreport.com/articles/27001930-us-womenssoccer-team-agrees-on-new-cba-with-us-soccer-after-labor-dispute 
Rehabilitation Act of 1973. Public Law 93-112, 87 Stat. 355.

Roach, B. L. (2010). The Lilly Ledbetter Fair Pay Act: paving the way for equal pay claims. Journal of Academic Perspectives, (2), 1-14.

Robinson, E. A. (2020). An equal world is an enabled world. Pulse (March 11). Retrieved from https://www.linkedin.com/pulse/equal-world-enabled-vice-president-mobile-engineering-services/

Romo, V. (2020). U.S. Women's Soccer Team Settles Part of Gender Discrimination Suit. NPR.org (December 1). Retrieved from https://www.npr.org/2020/12/01/940965382/u-s-womens-soccer-team-settles-part-of-genderdiscrimination-suit

Rowan, J. N. (2018). Equal protection for equal play: a constitutional solution to gender discrimination in international sports. Vanderbilt Journal of Entertainment and Technology Law, 20, 919-945.

Sharrow, E. A. (2020). How high school sports became the latest battleground over transgender rights. The Conversation (December 22). Retrieved from https://theconversation.com/how-high-school-sports-becamethe-latest-battleground-over-transgender-rights-151361

Sherman, M. (2020). Supreme Court rules existing civil rights law protects LGBT workers. Real Clear Politics (June 15). Retrieved from https://www.realclearpolitics.com/articles/2020/06/

Somin, A. (2010). The Obama administration: changing the rules of the Title IX game? Engage, 11(3), 26-32.

Stevenson, B. (2007). Title IX and the evolution of high school sports. Contemporary Economic Policy, 25(4), 486-505. https://doi.org/10.1111/j.1465-7287.2007.00080.x

Stolberg, S. G. (2009). Obama signs equal pay legislation. The New York Times (January 29). Retrieved from https://www.nytimes.com/2009/01/30/us/politics/30ledbetter-web.html

Turner, R. (2020). Title VII and the unenvisaged case: is anti-LGBTQ discrimination unlawful sex discrimination? Indiana Law Journal, 95, 227-268.

Valenti, A. (2021). LGBT employment rights in an evolving legal landscape: the impact of the Supreme Court's decision in Bostock v. Clayton County, Georgia. Employee Responsibilities and Rights Journal, 33, 3-23. https://doi.org/10.1007/s10672-020-09359-7

Villalobos, P. M. (1990). The Civil Rights Restoration Act of 1987: revitalization of Title IX. Marquette Sports Law Journal, 1, 149-169.

Weldon. W. (1990). Effects of the 1987 Civil Rights Restoration Act on educational policy and practice. The Journal of Negro Education, 59(2), 155-164. https://doi.org/10.2307/2295641

Women's Sports Foundation.org. History of Title IX. Retrieved from https://www.womenssportsfoundation.org/ advocacy_category/title-ix/ (last accessed April 12).

\section{Copyrights}

Copyright for this article is retained by the author(s), with first publication rights granted to the journal.

This is an open-access article distributed under the terms and conditions of the Creative Commons Attribution license (http://creativecommons.org/licenses/by/4.0/). 